\title{
Spontaneous pneumomediastinum and pneumorrhachis in a healthy girl
}

\author{
Jorge Rodrigues, ${ }^{1,2}$ Raquel Monteiro Costa, ${ }^{2}$ Joana Magalhães, ${ }^{2}$ Elisabete Santos ${ }^{2}$
}

'Department of Pediatrics, Hospital Pediátrico, Centro Hospitalar e Universitario de Coimbra EPE, Coimbra, Portugal ${ }^{2}$ Department of Pediatrics, Centro Hospitalar Tondela Viseu EPE, Viseu, Portugal

\section{Correspondence to} Dr Jorge Rodrigues; jorgefcrodrigues@gmail.com

Accepted 12 February 2021
Check for updates

(c) BMJ Publishing Group Limited 2021. No commercial re-use. See rights and permissions. Published by BMJ.

To cite: Rodrigues J, Costa RM, Magalhães J, et al. BMJ Case Rep

2021:14:e241077.

doi:10.1136/bcr-2020-

241077

\section{DESCRIPTION}

Primary spontaneous pneumomediastinum (SPM) is a rare clinical entity in children. It may arise in isolation or is associated with other complications. ${ }^{1-4}$ Benign and self-limited, it is usually managed conservatively, with spontaneous resolution in most cases. ${ }^{1-4}$

We present the case of a previously healthy 9-year-old girl was admitted after 3 days of productive cough, low-grade fever and sore throat. On palpation, anterior cervical pain with subcutaneous crackles and crepitus suggested subcutaneous emphysema. She showed no respiratory distress and had normal respiratory sounds on auscultation. Chest radiography (CR) revealed subcutaneous emphysema and gas in the retropharyngeal and mediastinal spaces (figure 1). Thoracic CT confirmed the diagnosis, with additional evidence of pneumorrhachis (figure 2). The patient stayed under supportive care (oxygen, bed rest and analgesics), with good clinical and radiological evolution. Serological and molecular testing for several infectious agents and respiratory function tests were normal. There was no recurrence during follow-up (12 months).

SPM is characterised by free air in the mediastinum not preceded by thoracic trauma, surgery or any other medical procedure, resulting from alveolar rupture and air dissection along the bronchovascular sheath. ${ }^{1}$ It is a rare condition in paediatric age, with an estimated incidence of $1 / 800$ to $1 / 15000$ patients, occurring predominantly in thin, tall, male adolescents. ${ }^{2}$ Under-recognised in children, SPM is especially rarely associated with pneumorrhachis, pneumothorax or pneumopericardium. ${ }^{3}$ Pneumorrhachis is a rare occurrence by itself. ${ }^{4}$ It can be classified as extradural or intradural, and extradural pneumorrhachis is the type most commonly associated with SPM, through mechanisms still poorly understood. ${ }^{4}$ Repetitive Valsalva manoeuvres, asthma, foreign body ingestion and/ or aspiration, oesophageal perforation, inhalation of illicit drugs and bronchopulmonary infection by Mycoplasma pneumoniae or respiratory syncytial virus are possible precipitating factors described in the literature. ${ }^{1-3}$ A minority of cases have no identifiable trigger. $^{1}$

Clinical presentation of SPM usually includes acute chest pain and dyspnoea, and less frequently neck pain, dysphonia or dysphagia. ${ }^{2}$ Pneumorrhachis does not have any pathognomonic signs and most patients usually present either as asymptomatic or with unspecific symptoms. ${ }^{4}$ Diagnosis of SPM and pneumorrhachis is usually primarily made

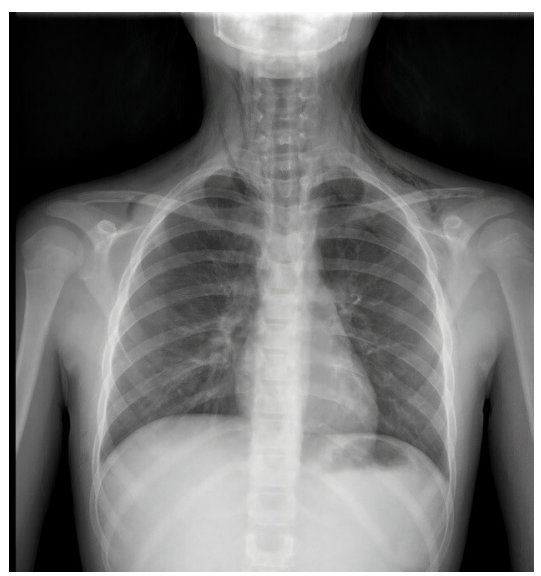

Figure 1 Posteroanterior chest radiograph showing pneumomediastinum and subcutaneous emphysema.

with CR. ${ }^{5}$ Even though chest CT scan is considered superior for diagnosis, it may prove unnecessary in many cases. ${ }^{12}$ Although there are no guidelines for managing SPM and pneumorrhachis, most patients improve under supportive care (bed rest, oxygen supplementation and analgesia). ${ }^{12}$ Other treatments reported in the literature include high flow oxygen therapy, systemic corticosteroids and hyperbaric oxygen administration. ${ }^{4}$ Close monitoring and anticipation of precipitating factors are required to avoid potentially serious complications, as cases of acute respiratory distress syndrome have been described. ${ }^{12}$ Treatment should therefore be individualised according to the patient's risk factors

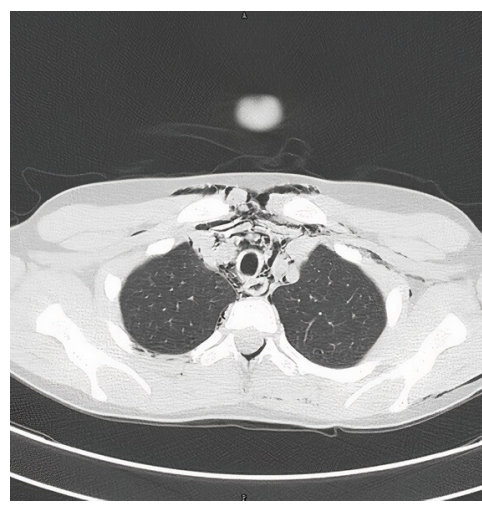

Figure 2 Axial CT images revealing air reaching the neck and axillary regions and located between superior mediastinal structures, as well as between intervertebral spaces. Great vessels of normal calibre and open airway. There are no signs of expansive lesions, parenchymal opacities, pleural effusion or pneumothorax. 
and clinical severity. ${ }^{46}$ Follow-up imaging is not usually required and prognosis is excellent overall. ${ }^{1}$

Subcutaneous emphysema should elicit SPM as differential diagnosis and require investigation to evaluate the location and extension of the air source. This case is notable for the absence of a triggering event and a rare association with pneumorrhachis.

\section{Patient's perspective}

At first, we were scared because we did not know what it meant for our daughter. After the medical team calmed our fears and we saw her evolution, we became more confident that everything would work out.

\section{Learning points}

Primary spontaneous pneumomediastinum is underdiagnosed in children and its association with pneumorrhachis is particularly rare.

- Multiple aetiologies should be excluded in the differential diagnosis and clinical signs of subcutaneous emphysema require investigation to evaluate the extension and location of the air source.

- Despite being benign and self-limiting in most cases, requiring conservative treatment, an early diagnosis is key to anticipate risk for complications.
Twitter Jorge Rodrigues @mrdraperjr

Contributors Regarding individual contributions, JR participated in the design of the case report, research of clinical data and writing of the manuscript. RMC participated in the design of the case report, research of clinical data and writing of the manuscript. JM contributed to the revision of the manuscript. ES contributed to the revision of the manuscript and selected the images in the article and analysis. Concept and design: JR, RMC and ES. Drafting of the manuscript: JR, JM and ES. Critical revision of the manuscript: All authors.

Funding The authors have not declared a specific grant for this research from any funding agency in the public, commercial or not-for-profit sectors.

Competing interests None declared.

Patient consent for publication Obtained.

Provenance and peer review Not commissioned; externally peer reviewed.

\section{REFERENCES}

1 Chalumeau M, Le Clainche L, Sayeg N, et al. Spontaneous pneumomediastinum in children. Pediatr Pulmonol 2001;31:67-75.

2 Gasser CR-B, Pellaton R, Rochat CP. Pediatric spontaneous pneumomediastinum: narrative literature review. Pediatr Emerg Care 2017;33:370-4.

3 Emiralioğlu N, Ozcan HN, Oğuz B, et al. Pneumomediastinum, pneumorrhachis and subcutaneous emphysema associated with viral infections: report of three cases. Pediatr Int 2015;57:1038-40.

4 Oertel MF, Korinth MC, Reinges MHT, et al. Pathogenesis, diagnosis and management of pneumorrhachis. Eur Spine J 2006;15 Suppl 5:636-43.

5 Wong K-sun, Wu H-M, Lai S-H, et al. Spontaneous pneumomediastinum: analysis of 87 pediatric patients. Pediatr Emerg Care 2013;29:988-91.

6 Heckman AJ, Mohseni M, Villanueva A, et al. Concurrent spontaneous pneumomediastinum and Pneumorrhachis. J Emerg Med 2018;54:e117-20.

Copyright 2021 BMJ Publishing Group. All rights reserved. For permission to reuse any of this content visit

https://www.bmj.com/company/products-services/rights-and-licensing/permissions/

BMJ Case Report Fellows may re-use this article for personal use and teaching without any further permission.

Become a Fellow of BMJ Case Reports today and you can:

- Submit as many cases as you like

- Enjoy fast sympathetic peer review and rapid publication of accepted articles

- Access all the published articles

Re-use any of the published material for personal use and teaching without further permission

\section{Customer Service}

If you have any further queries about your subscription, please contact our customer services team on +44 (0) 2071111105 or via email at support@bmj.com.

Visit casereports.bmj.com for more articles like this and to become a Fellow 